\title{
An Impact Study Of Social Networking Websites On The Youth In Our Society
}

\author{
Sumera Ishrat \\ Department of Social Work \\ University of Karachi
}

\begin{abstract}
The study focused to evaluate the trend of usage of social networking websites among the youth of our society and explore its impacts on their personal, academic and social life. Multistage sampling was adopted to collect data from the youth studying in University of Karachi. The sample consisted of 121 randomly selected respondents. The findings of the study indicated that the respondents use social networking websites only for interacting purpose rather than enhancement of knowledge. Respondents admitted that they had bad experiences during this practice. In spite of the frequent usage of these websites respondents wanted to send proper time on their academic activities, social gathering and their hobbies as well. The study concluded that the youth should be cautious in uploading their personal information on these websites. Parents should engage their children in family events, share experiences and discussing their issues to minimize the usage of social networking. On the other hand Government should take precautionary measures to save the potential, skills and above all the future of nation's youth.
\end{abstract}

Keywords: Social Networking Websites, Impact on Youth, Society.

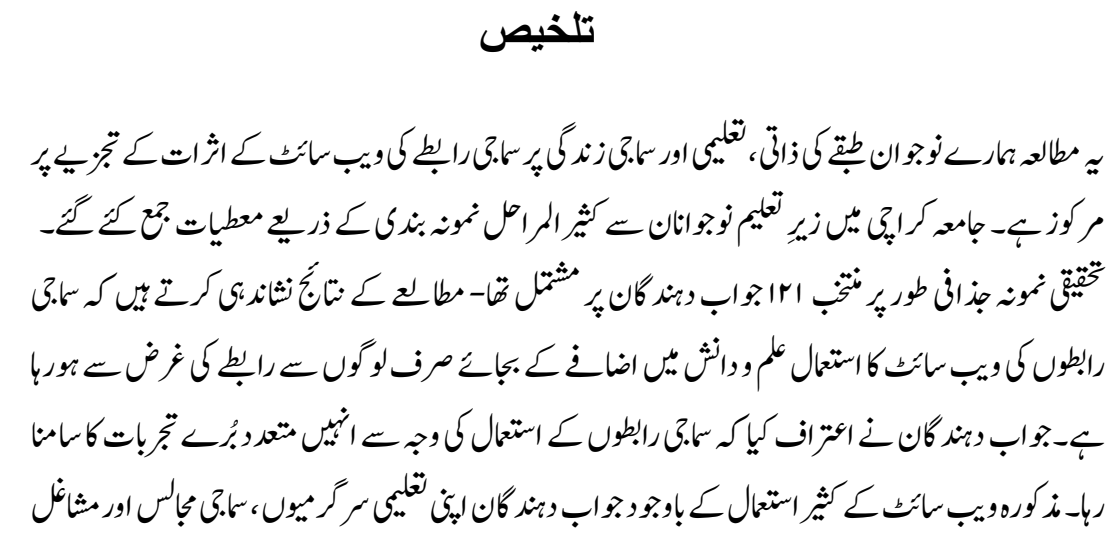




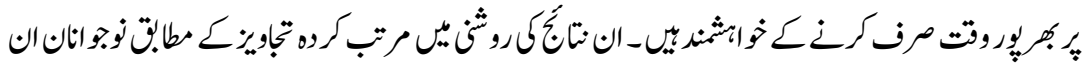

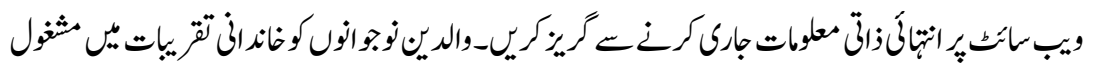

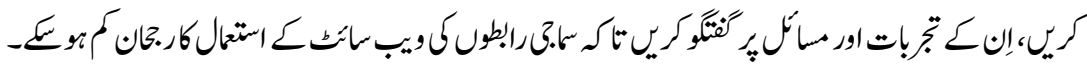

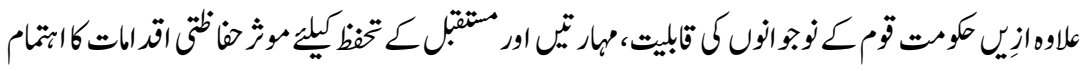

$$
\begin{aligned}
& -<
\end{aligned}
$$

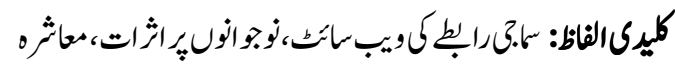

\section{Introduction}

Electronic mail (email) is the most frequently used application of the Internet. Many people, who have access to the Internet at school, home and at work place use the Internet for no other purpose than to send and to receive the mail. This has made communication between the strangers easier than ever. Chatting is one of the more popular activities on the internet, people can talk to anyone across the world.

Social network websites (SNS) are web-based services allowing individuals to construct a semi-public or public profile in a bounded system as well as to articulate a list of others so as to share connections, views and thoughts. However the type, classification and nature of these connections may differ from site to site. Mostly social networking websites are used to communicate with people who are already their friends or acquaintances in the social network sharing same mindset or same interests and views. Social networking websites are not only popular for providing a platform for chatting, sharing scraps, videos, pictures etc. but also for discussing social issues. However, certain issues yet require study and research like impact of SNS on youth's minds and loss of privacy as earlier people believed in keeping their data private but now they enjoy going public and showing wall posts, status updates, tweets and even every thrill of their lives (Jain, Gupta \& Anand, 2012).

Introduction of social online networking websites has facilitated communication. These are websites where users can create a profile and connect that to others to form an explicit personal network. They are web-based services that allow individuals to:

1. Construct a public or semi-public profile within a bounded system 
2. Articulate a list of other users with whom they share a connection and

3. View and traverse their list of connections and those made by others within the system.

Through social networking, people can use networks of online friends and group memberships to keep in touch with current friends, reconnect with old friends or create real life friendships through similar interests or groups. Besides establishing important social relationships, social networking members can share their interests with other likeminded members by joining groups and forums. Some networking websites can also help members to find a job or establish business contacts. Social networking websites have facilitated communication. Members of such websites can easily form groups (called the communities) and share their opinions through discussion threads, forums and polls. Though these websites serves good in many ways, it has negative effects too such as cybercrimes which has become a privacy threat to the people worldwide. Although advantageous in many ways by building new relationship and reconnecting with lost or old contacts, it also brought some behavioural changes among the youth, not only the behavioural changes but also their social behaviour and approaches. It has also ended up as a nightmare for a few people (Neelamalar \& Chitra, 2009).

\section{Emergence of Social Network Websites}

Neelamalar and Chitra (2009) stated the historical evolution of social networking websites, according to them early social networking websites included "Classmates.com" started in 1995, focusing on ties with former school mates, and "SixDegrees.com" launched during 1997, focusing on indirect ties. User profiles could be created, messages sent to users held on a friends list and other members could be sought out who have similar interests to the users-which could be found out from their profiles. Despite these new developments (that would later catch on and become immensely popular), these websites simply were not profitable and eventually shut down. It was even described by the websites owner as simply ahead of its time. Two different models of social networking that came about in 1999 were trust-based, developed by "Epinions.com" and friendship-based, such as those developed by Jonathan Bishop and used on some regional UK websites between 1999 and 2001. By 2005, one social networking service My Space was reportedly getting more page views than Google, with Facebook, a competitor, rapidly growing in size. In 2007, Face book began allowing externally-developed 
add-on applications, and some applications enabled the graphing of a user's own social network - thus linking social networks and social networking. Orkut was quietly launched on January 22, 2004 by Google, the search engine company which is now quite popular in most of the countries.

\section{Impact of Social Networking Websites on Youth}

According to United Nations (1981) Youth is the best understood as a period of transition from the dependence of childhood to adulthood's independence. For statistical purpose the organization define person between the ages of 15-24 as youth. Youth is the force for future of any nation and country's progress and development. Today Social media is essential for youth in the field of education to learn new trends in education, to improve writing and communicating skills, cultural promoting, religious and political information gathering and sharing links, better living style, growth and development of society. When these social networking websites started, youths got immediately attracted towards them as they found it very convenient to expand their social circle, chat with other fellow teenagers, share their personal photos and see other's data too without any security alert.

Nowadays, Facebook, Twitter, YouTube, Orkut are some of the most popular websites among our youth. These websites also have forum on social issues of our society. More than 150 pages related to social issues like corruption, human rights, girl's education etc. have emerged in the last few months in social networking websites.

These websites also facilitate Blog writing which is a latest trend it allows individual or group of users to record their opinions and information. Today almost every popular personality or celebrity maintains their blog and updating regularly as to enhance their popularity rate and get open views and suggestions from mass. Maintaining blogs also enables strengthening community ties and advancing key issues. People now don't rely much on traditional means of interaction instead they want to penetrate internet, social networking and derive the best output.

Social networking websites helps in integrating all the parts of the country including subcultures and minority groups who otherwise never get the physical means and space to practice their views and beliefs. Through social networking 
websites individuals can communicate with others irrespective of meeting face to face or present at a specified time. As these individuals are not aware of things they can use these websites and can raise their voices and can also participate.

With 17.5 million internet users Pakistan got a $7^{\text {th }}$ rank among the Asian top ten Internet countries. Social media having various impacts on youth's life in both ends some time impacts are in the favour of youth's social life and sometimes these impacts are negative to its user. It impacts upon young people who are growing up in an age where media is not about broadcast content from the TV, but it is about interactivity, multimedia and multi-tasking. And it impacts upon organizations who need to remain relevant to a new generation, and who find their own work and structures being changed by changing communication tools and patterns of communications (Shabir, et al., 2014).

Shabir, et al., (2014) quoted research conducted by BBC news during 2013 stated that $67 \%$ Facebook users comprised of the youth and students. It also marked that the negative use of social media occur when students involves themselves in unethical activities on social media portal, sharing of useless information, and posting such as images which are injurious national dignity and foreign relationship of country (Shabir, et al., 2014).

Tanya Byron points out in the Byron review that in part, young people are turning to digital connection because fears about traffic or 'stranger danger' have led to restrictions on how much young people are allowed to go out and socialize. Social media tools are woven into many young people's day-to-day lives. Young people are in conversation and communication with their peer groups using a wide variety of different media and media devices every day. 10 years ago, young people may have only been in touch with friends and peer-groups when hanging out at school, or meeting up in town. Now young people can be touch through instant messaging, social networks, online games and many other tools. Young people are growing up in a constantly connected society.

\section{Review of the Related Literature}

Lot of literature is available nowadays on the social networking sites and their impact on the youth of any nation, children, adolescence and families as during the last 5 years, usage of such websites has increased among pre-adolescents and adolescents. According to a latest poll, 22\% of teenagers log in more than 10 
times a day on to their favourite social media website, and more than half percentage of adolescents log more than once a day (James, 2009). Social media sites allow many tasks that were not possible offline. Participation in social media offers adolescents deeper benefits that extend into their view of community, self, and the world (Boyd, D., 2007). Today many parents are IT literate and use technology suitably well, comfortably and feel capable with the online websites that their children and adolescents are using. But some parents find it problematic to relate to their techno-savvy youngsters online. Such parents gradually lack an idea and connectivity with these new forms of socialization that play a vital role in their kid's lives (Palfrey J \& Gasser U, 2010).

According to an online survey conducted at July 2013 through Express Tribune and Express Urdu aimed to capture a Snapshot of the local internet users' perspective. Both Urdu and English websites and their media account were used to promote the survey in order to capture more diverse audience. The key findings of the survey were: out of 1,100 respondents half of the respondents belongs to 18-25 years in which males are more dominating, 94\% respondents are from urban areas (Karachi, Lahore and Islamabad), 974 respondents have high speed internet connections. Majority of the respondents use internet 5 hours a day, chatting is the number one activity for respondents on social networking websites, nearly all respondents have account on facebook. More than half of respondents say they have been a friend of someone on a social network whom they never meet in real life, and $82 \%$ respondents used proxies or other means to access blocked content.

\section{Objectives of the Study}

- To highlight the causes of using social networking websites among youth.

- To explore the trend of the usage of social networking websites among youth

- To find out the impacts of social networking sites on the youth specifically on their personal life, academic performance and social gatherings.

\section{Methodology}

In the present study, it has been emphasized to collect qualitative as well as quantitative data. The primary data was collected from University of Karachi. While secondary data was gathered from newspapers, magazines, research articles and internet. The population of the study was comprised on the students of faculty 
of social sciences, University of Karachi. Nine departments of this faculty were selected through systematic sampling technique. The sample was comprised on randomly selected 121 respondents from M.A (final year) from the sampled departments. This selection was made on the basis of the fact that students at this level are more involved in research work (assignments, projects, articles and thesis writing). Therefore, their usage of internet and social networking websites for discussion is comparatively more than their fellows at junior levels. A tailormade, pretested and self-administered questionnaire was used for data collection containing 46 items. Lastly, the data was analyzed by using frequency distribution tables.

\section{Findings of the study}

Table: 1

Personal information of the respondents

\begin{tabular}{|c|c|c|c|}
\hline \multicolumn{2}{|l|}{ Personal information } & Frequency & Percentage \\
\hline \multirow[t]{2}{*}{ Gender: } & Male & 68 & $56 \%$ \\
\hline & Female & 53 & $44 \%$ \\
\hline \multicolumn{2}{|l|}{ Total } & 121 & $100 \%$ \\
\hline \multirow[t]{3}{*}{ Age: } & 20-24 years & 81 & $67 \%$ \\
\hline & $25-29$ years & 27 & $22 \%$ \\
\hline & 30 years \& above & 13 & $11 \%$ \\
\hline \multicolumn{2}{|l|}{ Total } & 121 & $100 \%$ \\
\hline \multirow[t]{2}{*}{ Occupation: } & Part-time working & 75 & $62 \%$ \\
\hline & Student & 46 & $38 \%$ \\
\hline \multicolumn{2}{|l|}{ Total } & 121 & $100 \%$ \\
\hline \multirow[t]{2}{*}{ Family structure: } & Nuclear & 68 & $56 \%$ \\
\hline & Joint & 53 & $44 \%$ \\
\hline \multicolumn{2}{|l|}{ Total } & 121 & $100 \%$ \\
\hline \multirow{5}{*}{$\begin{array}{l}\text { Who else in family uses } \\
\text { social networking websites: }\end{array}$} & & & \\
\hline & Only me & 7 & $6 \%$ \\
\hline & Only elders & 36 & $30 \%$ \\
\hline & Siblings & 73 & $60 \%$ \\
\hline & All of them & 5 & $4 \%$ \\
\hline \multicolumn{2}{|l|}{ Total } & 121 & $100 \%$ \\
\hline
\end{tabular}

Majority of the respondents (56\%) are male while $44 \%$ of them (44\%) are female. Mostly (67\%) of them are 20-24 years old. 62\% of respondents are engaged in 
part-time jobs to cope their educational expenses. As far as their family structure is concerned $56 \%$ of them belong to nuclear family system. Lastly $60 \%$ of the respondents informed their siblings are also regular users of social networking websites. Due to these family units lack of adult monitoring has given the youth more independence in their habits.

Table: 2

Trend of using social networking websites

\begin{tabular}{|c|c|c|c|}
\hline \multicolumn{2}{|l|}{ Trend } & Frequency & Percentage \\
\hline \multirow{2}{*}{$\begin{array}{l}\text { Numbers of websites used by } \\
\text { respondents }\end{array}$} & $1-2$ & 40 & $33 \%$ \\
\hline & $3-4$ & 81 & $67 \%$ \\
\hline \multicolumn{2}{|l|}{ Total } & 121 & $100 \%$ \\
\hline \multirow[t]{6}{*}{ Most used websites } & Orkut & 0 & 0 \\
\hline & Facebook & 80 & $66 \%$ \\
\hline & Yaari & 0 & 0 \\
\hline & Skype & 0 & 0 \\
\hline & Gtalk & 41 & $34 \%$ \\
\hline & Yahoo & 0 & 0 \\
\hline \multicolumn{2}{|l|}{ Total } & 121 & $100 \%$ \\
\hline \multirow{2}{*}{$\begin{array}{l}\text { Daily usage of social networking } \\
\text { websites }\end{array}$} & Yes & 109 & $90 \%$ \\
\hline & $\mathrm{No}$ & 12 & $10 \%$ \\
\hline \multicolumn{2}{|l|}{ Total } & 121 & $100 \%$ \\
\hline \multirow[t]{5}{*}{$\begin{array}{l}\text { Hours in a week spent on these } \\
\text { websites }\end{array}$} & $\begin{array}{l}\text { Less than } 3 \\
\text { hours }\end{array}$ & 12 & $10 \%$ \\
\hline & 3-5 hours & 14 & $11 \%$ \\
\hline & 6-8 hours & 16 & $13 \%$ \\
\hline & 9-11 hours & 20 & $17 \%$ \\
\hline & $\begin{array}{l}12 \text { hours \& } \\
\text { more }\end{array}$ & 59 & $49 \%$ \\
\hline \multicolumn{2}{|l|}{ Total } & 121 & $100 \%$ \\
\hline
\end{tabular}

Mostly respondents $(67 \%)$ use 3-4 websites for social networking at a time. $66 \%$ of them use Facebook while 34\% use Gtalk for networking purpose. A huge majority of respondents (90\%) daily visit these websites whereas $49 \%$ of them spent 12 hours and more weekly on such websites. This is an alarming usage trend, if continuous; it will certainly increase and disturbed the whole life pattern of our youth. 
Table: 3

Reasons of using social networking websites

\begin{tabular}{|l|c|c|}
\hline Reasons & Frequency & Percentage \\
\hline To find new friends & 22 & $18 \%$ \\
\hline To find old friends & 16 & $13 \%$ \\
\hline To communicate existing friends & 48 & $40 \%$ \\
\hline To find someone who can share relation & 35 & $29 \%$ \\
\hline Total & $\mathbf{1 2 1}$ & $\mathbf{1 0 0 \%}$ \\
\hline
\end{tabular}

Mostly the respondents (40\%) the main reason of using social networking websites is to communicate with their friends.

Table: 4

\section{Utility of social networking websites}

\begin{tabular}{|l|c|c|}
\hline Utility & Frequency & Percentage \\
\hline I have more friends now & 27 & $22 \%$ \\
\hline I am able to connect with existing friend easily & 28 & $23 \%$ \\
\hline I have found my life partner through these websites & 15 & $12 \%$ \\
\hline I found great pleasure to enjoy my leisure & 53 & $43 \%$ \\
\hline Total & $\mathbf{1 2 1}$ & $\mathbf{1 0 0 \%}$ \\
\hline
\end{tabular}

Most of the respondents (43\%) highlight the utility of social networking websites as it is the best mean to enjoy their leisure. Although these websites can be utilize for enhancing abilities, knowledge, modern trends of learning etc. but our youth has confined themselves with the most least use of this technology. 
Table: 5

Impact of social networking websites

\section{a) Personal Life}

\begin{tabular}{|c|c|c|c|}
\hline \multicolumn{2}{|l|}{ Impact } & Frequency & Percentage \\
\hline \multirow[t]{2}{*}{ Influence life style: } & Yes & 86 & $71 \%$ \\
\hline & $\mathrm{No}$ & 35 & $29 \%$ \\
\hline \multicolumn{2}{|l|}{ Total } & 121 & $100 \%$ \\
\hline \multirow[t]{2}{*}{ Had bad experience: } & Yes & 73 & $60 \%$ \\
\hline & $\mathrm{No}$ & 48 & $40 \%$ \\
\hline \multicolumn{2}{|l|}{ Total } & 121 & $100 \%$ \\
\hline \multirow{2}{*}{$\begin{array}{l}\text { Created negative impacts on } \\
\text { personal life: }\end{array}$} & Yes & 105 & $87 \%$ \\
\hline & No & 16 & $13 \%$ \\
\hline \multicolumn{2}{|l|}{ Total } & 121 & $100 \%$ \\
\hline \multirow{4}{*}{$\begin{array}{l}\text { If yes, nature of negative } \\
\text { impacts: }\end{array}$} & Loss of privacy & 34 & $32 \%$ \\
\hline & Loss of time & 32 & $31 \%$ \\
\hline & $\begin{array}{l}\text { Increased rely on } \\
\text { electronics }\end{array}$ & 13 & $12 \%$ \\
\hline & $\begin{array}{l}\text { Minimum emotional } \\
\text { bonding }\end{array}$ & 26 & $25 \%$ \\
\hline \multicolumn{2}{|l|}{ Total } & 105 & $100 \%$ \\
\hline \multirow{2}{*}{$\begin{array}{l}\text { Missed sleep or food due to } \\
\text { the activities on these } \\
\text { websites: }\end{array}$} & Yes & 40 & $33 \%$ \\
\hline & No & 81 & $67 \%$ \\
\hline \multicolumn{2}{|l|}{ Total } & 121 & $100 \%$ \\
\hline
\end{tabular}

A vast majority of the respondents $(71 \%)$ claimed that these websites influence their life style in term of dressing sense, carrying accessories, make-over style and so on. Beside this, $60 \%$ of them admit that they had bad experiences while using these websites and realized that they not only wasted time and lost their privacy as well. In spite all these facts, an encouraging aspect is that the respondents never ignored their basic necessities over this habit. 
b) Social Life

\begin{tabular}{|c|c|c|c|}
\hline \multicolumn{2}{|l|}{ Social impacts } & Frequency & Percentage \\
\hline Attended family gathering/events: & Yes & 83 & $69 \%$ \\
\hline & No & 38 & $31 \%$ \\
\hline \multicolumn{2}{|l|}{ Total } & 121 & $100 \%$ \\
\hline \multirow[t]{2}{*}{ Fulfills responsibilities: } & Yes & 62 & $51 \%$ \\
\hline & No & 59 & $49 \%$ \\
\hline \multicolumn{2}{|l|}{ Total } & 121 & $100 \%$ \\
\hline
\end{tabular}

Beside frequent use of social networking websites mostly respondents (83\%) attend family gatherings/events and $62 \%$ of them fulfil their responsibilities whole heartedly. This is also a positive sign that the youth still regard family values and their responsibilities. Activities related to social networking affected our society at large but parents and family members can minimize this usage by providing the youth opportunities to share their experiences with them.

\section{c) Academic Performance}

\begin{tabular}{|c|c|c|c|}
\hline \multicolumn{2}{|l|}{ Academic impacts } & Frequency & Percentage \\
\hline \multirow[t]{2}{*}{ Effect academic performance: } & Yes & 54 & $45 \%$ \\
\hline & No & 67 & $55 \%$ \\
\hline \multicolumn{2}{|l|}{ Total } & 121 & $100 \%$ \\
\hline \multirow[t]{2}{*}{$\begin{array}{l}\text { Got assistance in academic activities \& } \\
\text { tasks: }\end{array}$} & Yes & 24 & $20 \%$ \\
\hline & No & 97 & $80 \%$ \\
\hline \multicolumn{2}{|l|}{ Total } & 121 & $100 \%$ \\
\hline \multirow[t]{2}{*}{$\begin{array}{l}\text { Grade could be better if social } \\
\text { networking websites not used: }\end{array}$} & Yes & 59 & $49 \%$ \\
\hline & No & 62 & $51 \%$ \\
\hline Total & & 121 & $100 \%$ \\
\hline
\end{tabular}

$55 \%$ of the respondents informed that their academic performance is not affected by their habit of social networking. Mostly respondents $(80 \%)$ admit that they don't academically utilize this platform. Alongwith this $51 \%$ of the respondents think that these websites don't assist them to achieve better grades. 
Table: 6

Opinion about the usage trend of social networking websites

\begin{tabular}{|l|l|c|c|}
\hline Opinion & Frequency & Percentage \\
\hline $\begin{array}{l}\text { If you are not using social } \\
\text { networking websites then your } \\
\text { activities will be: }\end{array}$ & Studying & 26 & $22 \%$ \\
\hline & $\begin{array}{l}\text { Hanging out with } \\
\text { friends }\end{array}$ & 21 & $17 \%$ \\
\hline & Reading & 53 & $44 \%$ \\
\hline & $\begin{array}{l}\text { Activities of } \\
\text { interest }\end{array}$ & 21 & $17 \%$ \\
\hline Total & $\mathbf{1 2 1}$ & $\mathbf{1 0 0 \%}$ \\
\hline
\end{tabular}

Most of the respondents (44\%) stated that instead of social networking activities they like to read different books while $22 \%$ of the respondents wanted to spent proper time on their studies whereas $17 \%$ of them wish to hang-out with their friends and do other activities of their interest. It shows that the respondents are using social working websites but they are interested to indulge themselves in activities which make them relax, refresh and boost their energy. This is also a healthy sign that our youth has realized the utility of real world activities.

\section{Conclusions}

The world has been made flat by the World Wide Web. Today we live in a world where contacting someone, sharing our journey as well as our thoughts is just one click away. Social networking websites are now available to cater one's immediate social needs. These networking websites have made it possible for us to chat with friends who live in distant places as well as share pictures and videos with them instantly. The youth today uses social networking websites in order to pour out all their ideas and emotions. They post or tweet anything that they have in mind as well as 'like' or 'share' posts, pictures or links which they think are interesting. They can even use these to cheer up friends who just had a bad day by posting something funny and then tagging their friends. Apart from expressing ideas and emotions, the youth use these websites in order to communicate with other people and keep in touch with their friends. It makes the communication easier and faster. Due to this, parents, educators and social scientists are concerned about the effects of such websites on youth. These concerns are ranged 
from youth privacy, safety, psychological well-being, social development and academic performance. Usually they spend their extra time in chatting rather than knowledge enhancement. Indeed, the youth are able to benefit from various features of social networking websites; however, there are also negative effects which go with this. Cyber bulling is one of the major negative aspects of these websites. No doubt, social networking websites are of great help in youth's daily life; however, it has positive and negative effects which depend on how a person will utilize it.

It is concluded from the present study that the trend of usage social networking websites is in infancy phase in Pakistani youth. They are frequent users of these websites but still they regard family values and customs. They are in-need of proper guideline, counselling and monitoring for purposeful utilization of these most modern platforms.

\section{Recommendations}

- Keep the information accessible only to people which are listed in friend's list.

- Do not accept the friendship request from strangers. This is the first mistake that cyber criminals use against the users.

- Don't post the very personal information on the profile, be cautious while posting photos and do not post current location during a tour.

- Do not post negative things and experiences about life, one such mistake can cause havoc in future.

- Avoid using social networking websites in work hours. As it affects work performance.

- The government should take initiative and design a charter of policy for the sim card companies in order to limit their internet packages, $2 \mathrm{G}, 3 \mathrm{G}, 4 \mathrm{G}$ etc. technologies and restrict one single duration for availing these packages.

- Parents and other family members should keep a constant monitoring on the online activities of their children, make them realize the worth of their time, and engage them in family events as well as constructive activities.

- Parents must spend quality time with their children, listen to them and provide opportunities to express their emotions, thoughts, ideas as well as encourage them to share their experience. 
- The government should also take measures on war-footing towards the wide spreading of Wi-Fi connections. The relevant terms and policies should also be reviewed by the concerned authority.

\section{Endnotes}

1. Boyd, D. (2007). Why Youth (Heart) Social Network Sites, The Role of Networked Publics in Teenage Social Life, In: Buckingham D. (ed.) MacArthur Foundation Series on Digital Learning: Youth, Identity, and Digital Media Volume. Cambridge, MA: MIT Press.

2. Haqu, J. \& Popalzai, S. (2013). Pakistan Internet Use Survey 2013, Express Tribune August, 20 ${ }^{\text {th }}$, 2013, http://tribune.com.pk/story/591004/pakistaninternet-use-survey-2013/

3. Jain, Madhur, Raj, Gupta, Palak \& Anand, Nitika (2012). Impact of Social Networking Sites in the Changing Mindset of Youth on Social Issues-A Study of Delhi-NCR Youth, Research World-Journal of Arts, Sciences \& Commerce, vol. III, Issue 2:2, pp.36-43

4. James, Steyer (2009). Is Technology Networking Changing Childhood? A National Poll by Common Sense Media, San Francisco.

5. Neelamalar, M. \& Chitra, P. (2009). New Media and Society: A Study on the Impact of Social Networking Sites on Indian youth.

6. Palfrey, J., Gasser, U. \& Boyd, D. (2010). Empowering Parents and Protecting Children in an Evolving Media Landscape, Cambridge, MA: Berkman Centre for Internet and Society at Harvard University.

7. Secretary General's Report to the General Assembly, A/36/215. 1981.

8. Shabir, et al. (2014). The Impact of Social Media on Youth: A Case Study of Bahawalpur City, Asian Journal of Social Sciences \& Humanities, vol. 3:4.

\section{References}

Bargh, J. A. \& McKenna, K. Y. A. (2004). The Internet and Social Life, Annual Review of Psychology.

Barkhuus, L. \& Tashiro, J. (2010). Student Socialization in the Age of Facebook, In Proceedings of CHI. New York: ACM Press.

Lenhart, A., Purcell, K. \& Smith, A. (2010). Social Media and Young Adults, Washington, DC, Pew Research Center. 
Subrahmanyam, K., Reich, S., Waechter, N. \& Espinoza, G. (2008). Online and Offline Social Networks: Use of Social Networking Sites by Emerging Adults, Journal of Applied Developmental Psychology, vol.29, pp.420-433.

The Byron Review Action Plan. (June 2008). http://webarchive.nationalarchives.gov. uk/20130401151715/http://www.education.gov.uk/publications/eOrderingDo wnload/Byron_Review_Action_Plan.pdf.

Turkle, S. (2011). Alone Together: Why We Expect More from Technology and Less from Each Other, New York, Basic Books.

Tyler, T. R. (2002). Is the Internet Changing Social Life? It Seems that the More Things Change the More they Stay the Same, Journal of Social Issues, vol.58, pp.195-205

Dr. Sumera Ishrat is Assistant Professor in the Department of Social Work, University of Karachi. 